\title{
Use of Iron Ore Overburden As a Precursor for the Synthesis of an Alkali-activated Binder
}

\section{Marina Filizzola Oliveira ${ }^{1}$, Naim Sedira $^{2}$, Ana Cláudia Guimarães ${ }^{3}$, Fernando Lameiras ${ }^{1}$, and João Castro-Gomes ${ }^{2}$}

${ }^{1}$ CDTN Centro de Desenvolvimento da Tecnologia Nuclear - CDTN/CNEN Avenida Presidente Antônio Carlos, 6.627 - Campus da UFMG - Pampulha. CEP 31270-901 - Belo Horizonte, MG, Brazil

${ }^{2}$ C-MADE - Centre of Materials and Building Technologies, University of Beira Interior - Faculty of Engineering, R. da Calçada Fonte Lameiro 10, 6200-358 Covilhã, Portugal

${ }^{3}$ Université de Pau et des Pays de I'Adour, Campus Montaury, Allée du Parc Montaury, 64600 Anglet, França

\section{Abstract}

The iron ore beneficiation process produces a large quantity of waste. Mining companies are looking for technologies that make it possible to dispose of their waste and transform it into raw material for the manufacture of products that can be applied

Corresponding Author: Marina Filizzola Oliveira filizzolamarina@gmail.com

Received: 7 January 2020 Accepted: 21 April 2020 Published: 3 May 2020

Publishing services provided by Knowledge E

(c) Marina Filizzola Oliveira et al. This article is distributed under the terms of the Creative Commons Attribution License, which permits unrestricted use and redistribution provided that the original author and source are credited.

Selection and Peer-review unde the responsibility of the STARTCON19 Conference Committee.

\section{G OPEN ACCESS} in other areas, for example in the production of concrete, mortar, ceramics, blocks, and bricks. This study aimed at the feasibility of using a calcined iron ore overburden as a precursor of alkali-activated binders. For alkaline activation of the precursors, sodium hydroxide solution and sodium silicate were used in the atomic proportions $\mathrm{Al} / \mathrm{Na}=$ 2 and $\mathrm{Si} / \mathrm{Al}>0,7$. Mineralogical and microstructural characterization was carried out by $X$-ray diffraction (XRD) and scanning electron microscopy with energy-dispersive $X$-ray spectroscopy (SEM/EDX). Tests of compressive strength were performed for the binders with 7, 14, 21 and 28 of curing days. The results of the analyses demonstrated that the properties of the alkali-activated binders produced with the overburden were similar to the binders obtained by precursors used traditionally. It was found, therefore, that the calcined iron ore overburden, can be considered a precursor for obtaining alkaline activated binders

\section{Introduction}

The growing concern about environmental protection and prevention against damages caused by production processes encourages researchers to develop alternatives and new technologies that allow increasing the efficiency of the process without disregarding environmental commitment. In this context, the alkali-activated binders have been distinguished by their good physical and chemical properties, which translates in high mechanical strength and durability, resistance to fire and chemical attacks and resistance to sudden temperature variations [1]. Another advantage of these novel binders is their cost. They can be considered a low-cost material once the raw material 
can be provided by industrial waste or clay-rich in aluminosilicate, being this last one a material that occurs in abundance in the earth's crust [2]. Moreover, its production process does not require large amounts of energy since it can be cured at temperatures below $100^{\circ} \mathrm{C}[3]$.

The good characteristics of alkali-activated binders associated with their economic viability enable their use in several industrial sectors, increasing productivity and reduction of environmental impacts of the processes. The many possible uses of geopolymer binders are revealed by their use in multiple sectors such as metallurgy, nonferrous metal foundries, plastics industry, automotive, aerospace and even in the artistic production process. [4]

Among its many utilities, alkali-activated binders are much useful in civil engineering, where alkali-activated binders could be an alternative binder to the Portland cement [5]. The greatest difference between these two binders is $\mathrm{CO}_{2}$ emission. Geopolymer binders are known by their lower $\mathrm{CO}_{2}$ emission, that can rich a rate of $90 \%$ less than Portland cement because of the production process [6]

In general, alkali-activated binders are synthesized by the alkaline activation reaction of aluminosilicates materials ( $\mathrm{rich}$ in $\mathrm{SiO}_{2}$ and $\mathrm{Al}_{2} \mathrm{O}_{3}$ ). The reaction starts when the alumina (Al) and silica ( $\mathrm{Si}$ ) are dissolved in the alkaline activator solution, followed by an orientation of the dissolved species. In the next step, a polymerization reaction performed and the product is cured to form the binder. The binder formed has a predominantly amorphous aluminosilicate structure of $\mathrm{SiO}^{4-}$ and $\mathrm{AlO}^{4}$ tetrahedra forming a three-dimensional network [7].

The polymerization reaction efficiency and binder characteristics depend on the chemical and mineralogical compositions of raw material used as well as the molarity of the activators and the precursor to activator (P/A) ratios. According to Davidovits [8], certain atomic ratios must be respected to obtain optimum results providing good mechanical and durability properties.

In the process to obtain geopolymer binders, the raw materials must be rich in silica and alumina, usually used after a heat treatment that turns the material into the amorphous phase (more reactive). The usually industrial wastes used are fly ash, calcined clays, natural pozzolans and metakaolin [9]. The context of environmental awareness and concern about the impact of industrial activities indicates the importance of seeking solutions for the waste generated by many industrial processes such as mining activities.

In this sense, the overburden of the mining process is considered a residue of the mining activity. The present study aims to find a viable use for the overburden provided 
by mining activities as a precursor to producing alkali-activated binders. Besides, to investigate the feasibility of re-using a calcined iron ore overburden material (Metakflex ${ }^{\circledR}$ ) as a precursor for an alkali-activated binder.

\section{Experimental Procedures}

\subsection{Materials}

\subsubsection{Precursors}

The materials used in this study were calcined iron ore overburden, commercially named as Metakflex ${ }^{\circledR}$.

Grain size distributions curves of the retained fractions overburden are given in Fig. 1. The mean particle size (d50) was determined as $17.26 \mu \mathrm{m}$.

The elemental composition of this material, as detected from XRF analysis, is given in Table 1. It can be noted that this material is rich in $\mathrm{SiO}_{2}$ and $\mathrm{Al}_{2} \mathrm{O}_{3}$, which proves that the material studied contains alumino-silicate minerals.

The XRD patterns of the material in Fig 2 show the presence of diffraction peaks corresponding to the crystalline phases Muscovite $(M)$, Kaolinite $(K)$, Hematite $(H)$ and Quartz (Q). In the graph, there is also a notable existence of noise that may be associated with the presence of amorphous phases in the material.

\subsubsection{Alkaline activator}

For the alkaline activation of the material, highly alkaline activator solutions were used such as (sodium silicate and sodium hydroxide). Sodium hydroxide $(\mathrm{NaOH})$ was dissolved using distilled water to provide a $10 \mathrm{M}$ alkaline solution. $\mathrm{SH}$ solution was prepared one day before using it. Also, a commercial sodium silicate supplied by Uimica Sulfal Limited (consisting of $32.6 \% \mathrm{SiO}_{2}, 15.0 \% \mathrm{Na}_{2} \mathrm{O}$ and $52.7 \% \mathrm{H}_{2} \mathrm{O}$ ). For the preparation of the alkaline solution, a ratio of SS/SH activators ratio equal to 2 was based on preliminary studies [10].

\subsection{Alkali-activated binder preparation}

A calcined iron ore overburden (Metakflex ${ }^{\circledR}$ ) used raw material for the synthesis of an alkali-activated binder. The precursor was mixed with the activator solution $\left(\mathrm{Na}_{2} \mathrm{SiO}_{3}\right.$ and 
$\mathrm{NaOH}$ ) with precursor/activator ratio 2.5 at room temperature, enabling the formation of alkali-activated pastes. In all mixtures, the ratio of the precursor to the solution was determined so that all compositions reached the $\mathrm{Al} / \mathrm{Na}=2.07$ and $\mathrm{Si} / \mathrm{Al}=0.75 \mathrm{molar}$ ratios.

The mixtures (raw material and activator solution) were manually molded into cylindrical molds with dimensions $3,5 \times 7 \mathrm{~cm}$ (diameter $\times$ height). The molds were vibrated on a vibrating table for 10 minutes to remove the bubbles formed while filling the molds to produce specimens. After molding the specimens were cured in an oven at $60^{\circ}$ for $24 \mathrm{~h}$, followed by curing at room temperature for 1,7 and 28 days.

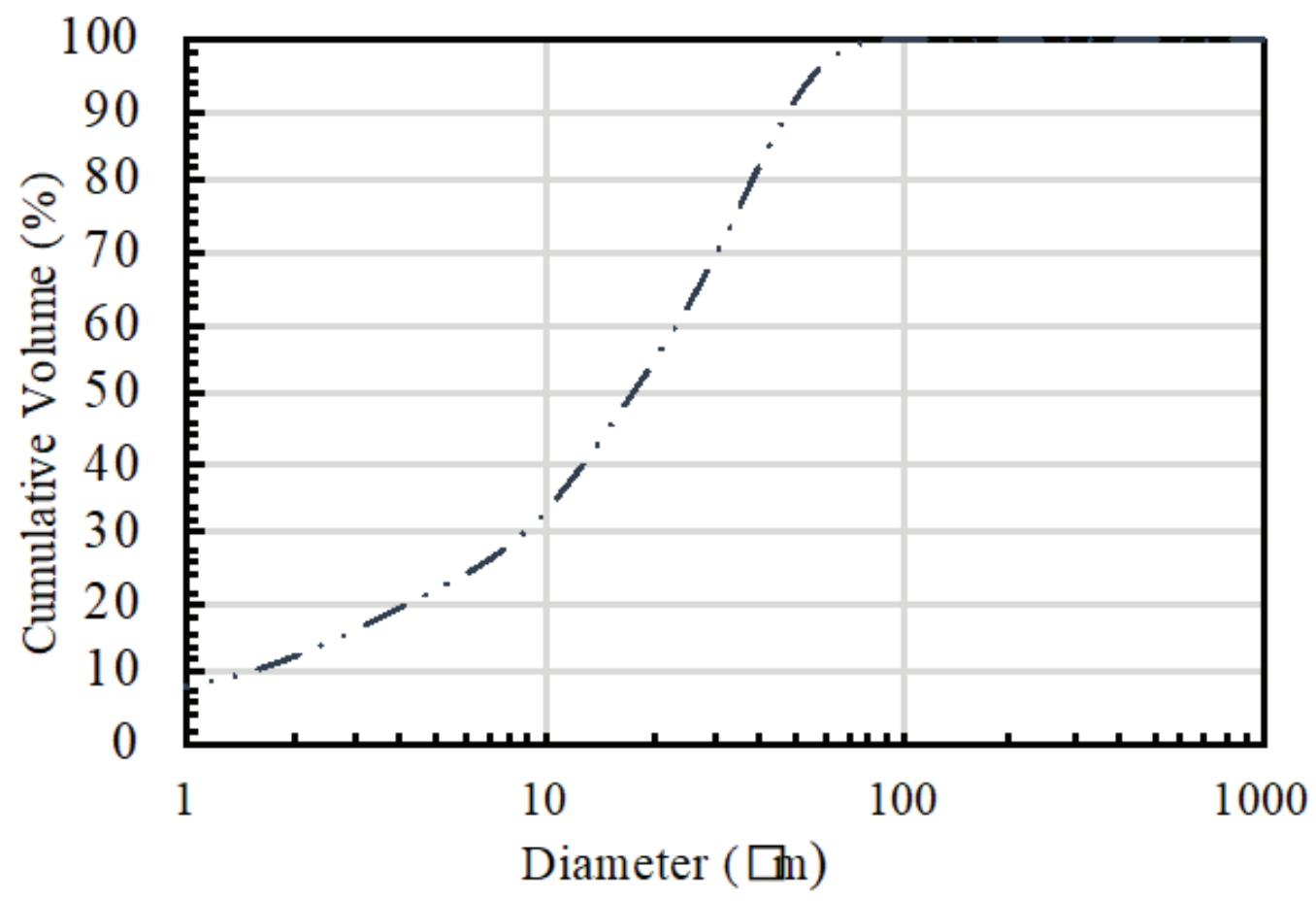

Figure 1: Granulometric distribution of iron ore overburden.

\subsection{Compressive strength}

The specimens were submitted to the compressive strength as a mechanical test using a hydraulic press with the application of axial force. The breaking strength of each specimen was observed. To perform the test, the species had the flat surfaces sanded with sandpaper 80. Measurements of the size and weighing of the species were then made. The compressive strength tests were performed on three specimens made with iron ore overburden which had a cylindrical shape with dimensions $3.5 \times 7 \mathrm{~cm}$ 
TABLE 1: Chemical compositions of the precursor material iron ore overburden determined by XRF analysis.

Oxides (wt.\%)
$\mathrm{SiO}_{2}$
$\mathrm{Al}_{2} \mathrm{O}_{3}$
$\mathrm{Fe}_{2} \mathrm{O}_{3}$
$\mathrm{TiO}_{2}$
$\mathrm{~K}_{2} \mathrm{O}$
$\mathrm{P}_{2} \mathrm{O}_{5}$
$\mathrm{MgO}$
$\mathrm{MnO}$
$\mathrm{BaO}$

\begin{tabular}{|c|}
\hline $\begin{array}{c}\text { Iron ore } \\
\text { overburden }\end{array}$ \\
\hline 41.1 \\
\hline 33.8 \\
\hline 15.4 \\
\hline 5.7 \\
\hline 2.5 \\
\hline 0.6 \\
\hline 0,3 \\
\hline 0,3 \\
\hline 0,1 \\
\hline
\end{tabular}

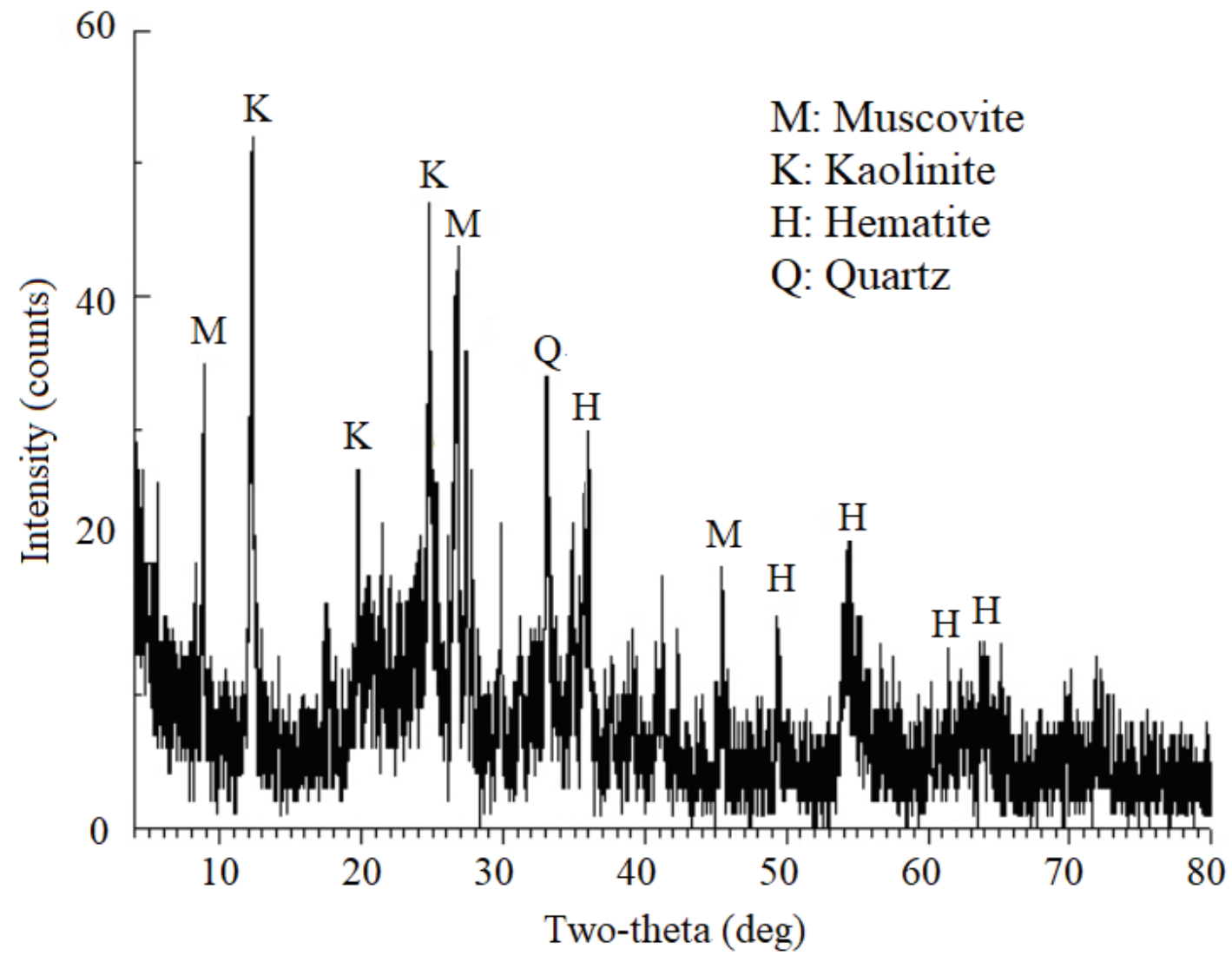

Figure 2: X-ray diffractogram of iron ore overburden.

(diameter $\mathrm{x}$ height). Therefore, the specimens were cured for 1, 7 and 28 days before the compressive tests. 


\subsection{Microstructure characterization}

The calcined iron ore overburden raw material and the calcined iron ore overburden alkali-activated binder were analyzed for their physical and microstructural aspects using the SIGMA VP model, manufactured by Carl Zeiss Microscopy. Meanwhile, the punctual chemical compositions of the ligands quantified by an X-ray dispersive spectroscopy (EDS) system coupled with SEM using Bruker Nano GmbH X-Flash 410-M model. SEM images were obtained by backscattered electrons, an electron acceleration voltage of $10 \mathrm{kV}$, a beam aperture of $120 \mu \mathrm{m}$ and a working distance of $12.4 \mathrm{~mm}$.

For the SEM/EDS analysis, the sample was prepared by metallography techniques which consist of the embedding and polishing of the surface of the sample. The sample was embedded in crystal resin at room temperature. After 24 hours it polished with 80 , 100, 220, 320, 400 and 600 silica carbide scales, and then polished with $3 \mu \mathrm{m}$ diamond paste. Then the samples were metalized with gold to conduct the electrons from the beam to the sample. The alkaline activated ligand sample chosen for microstructure analysis was a fragment of the 28 days old fractured specimen.

\section{Results}

\subsection{Compressive strength}

The compressive strength results of the alkali-activated binder are shown in table 2 . After one day of cure give a compressive strength of 23.4 MPa, which corresponding to $92.74 \%$ from the final compressive strength result at 28 days. The compressive strength of the alkali-activated binder has increased significantly on the first day and slowly after the first day until the 28th days of cure. Some alkali-activated binders made with traditional materials such as metakaolin, under conditions similar to that presented in this work, presented compressive strength values around $12 \mathrm{MPa}$ after 28 days of cure [11].

\subsection{SEM-EDS analysis}

The morphology and surface chemical composition of the iron ore overburden and a fragment of calcined iron ore overburden alkali-activated binders cured for 28 days are shown in Fig. 3 and Table 2, respectively. 
The raw material (calcined iron ore overburden) morphology indicated irregularly shaped particles as shown in Fig.3a.

For the SEM-EDS analysis, the precursor (Iron ore overburden) and the alkali-activated binder matrix, Spots 1 and 2 were identified by X-ray energy dispersive spectroscopy (EDS) as shown in Table 2. The chemical composition of the matrix showed a Si/Al ratio of 2.57. Spot 1 was identified as iron oxide. However, spot 2 identified as a nonreactive aluminosilicate. The presence of iron oxide in this sample was already expected because the material studied is overburden from the exploitation of iron ore.

TABLE 2: Compressive strength of the calcined iron ore overburden alkali-activated binder.

\begin{tabular}{l|c|} 
Curing time (days) & $\begin{array}{c}\text { Compressive strength of } \\
\text { the Alkali-activated binder } \\
\text { (MPa) }\end{array}$ \\
\hline 1 & 23.4 \\
7 & 23.9 \\
\hline 28 & 25.1 \\
$\begin{array}{l}\text { Compressive strength } \\
\text { increase (\%) (between 1 } \\
\text { and 28 days) }\end{array}$ & 7.26 \\
\hline
\end{tabular}

TABLE 3: Elemental composition of the matrix and points of 1 and 2 (binder produced with calcined iron ore overburden).

Element (\%)
$\mathrm{O}$
$\mathrm{Si}$
$\mathrm{Al}$
$\mathrm{Fe}$
$\mathrm{Na}$
$\mathrm{Ca}$
$\mathrm{P}$
$\mathrm{Mg}$
$\mathrm{Ti}$
$\mathrm{Si} / \mathrm{Al}$

\begin{tabular}{|c|}
\hline $\begin{array}{c}\text { Iron ore } \\
\text { overburden }\end{array}$ \\
\hline 47.4 \\
\hline 6.9 \\
\hline 7.1 \\
\hline 6.4 \\
\hline- \\
\hline 30.5 \\
\hline 0.1 \\
\hline 0.2 \\
\hline 0.5 \\
\hline
\end{tabular}

\begin{tabular}{|c|c|}
\hline \multicolumn{2}{|c|}{ Alkali-a } \\
\hline Matrix \\
\hline 55.4 \\
\hline 25.4 \\
\hline 9.9 \\
\hline 2.7 \\
\hline 5.2 \\
\hline 0.5 \\
\hline 0.5 \\
\hline 0.3 \\
\hline- \\
\hline 2.6 \\
\hline
\end{tabular}

Alkali-activated binder

\begin{tabular}{|c|c|}
\hline Spot 1 & Spot 2 \\
\hline 33.4 & 33.3 \\
\hline- & 37.2 \\
\hline- & 18.4 \\
\hline 63.4 & 8.8 \\
\hline- & 2.4 \\
\hline- & - \\
\hline- & - \\
\hline- & - \\
\hline 3.2 & - \\
\hline
\end{tabular}

\section{Conclusions and Future Studies}

This study aimed to investigate the alkaline activation of calcined iron ore overburden. The precursor was activated by a solution of $\mathrm{NaOH}$ and $\mathrm{Na}$ silicate $\left(\mathrm{Na}_{2} \mathrm{SiO}_{3}\right)$ which the precursor to the activator ratio is equal to 2.5 . The results showed that: 


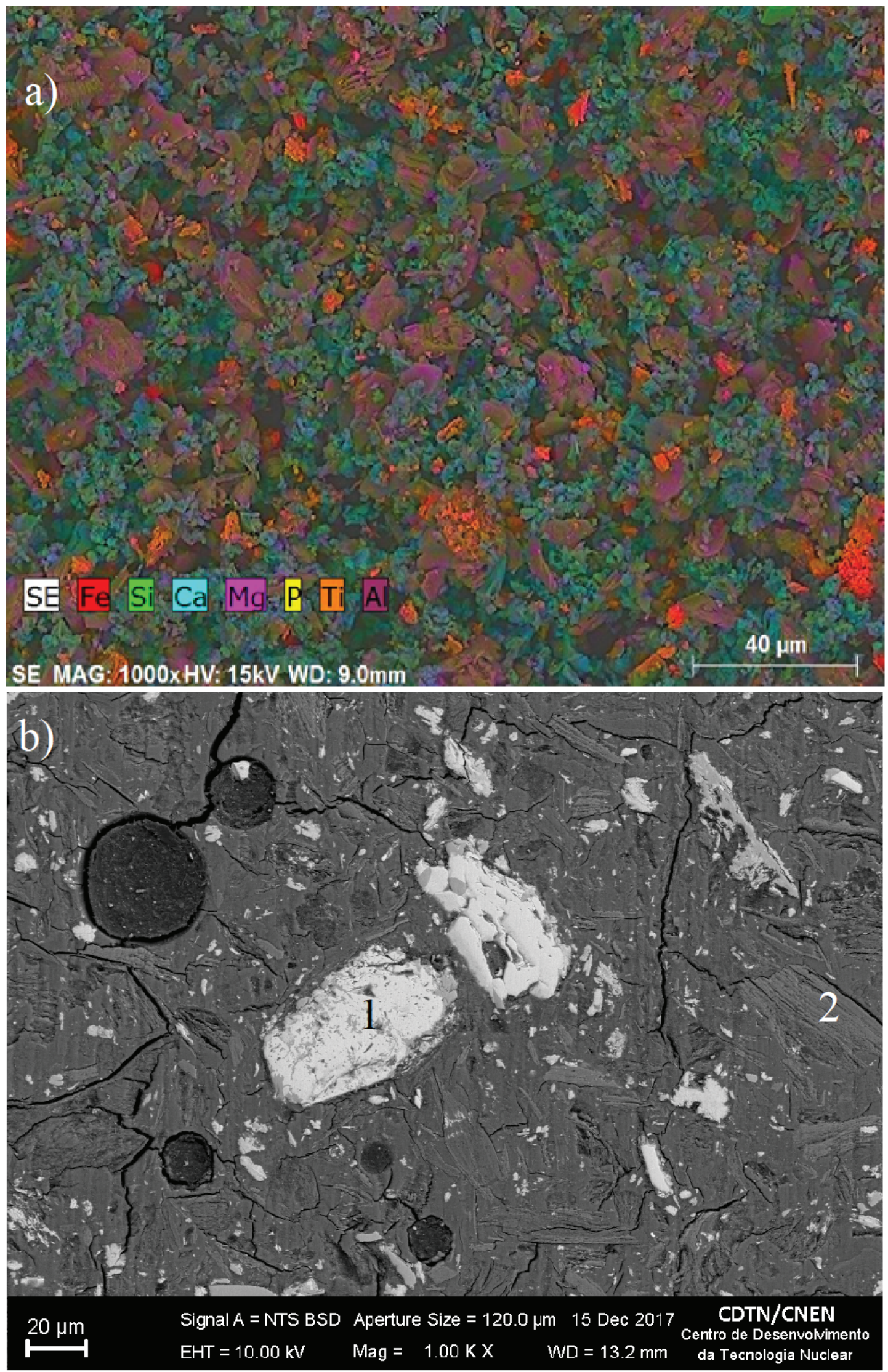

Figure 3: SEM micrographs for a) iron ore overburden raw material, b) representative fracture surface for alkali-activated pastes at the age of 28 days. 
- The compressive strength of the calcined iron ore overburden alkali-activated material had a high compressive strength on the first day. However, this compressive strength increased slowly by the curing time.

- The microstructure analysis of the calcined iron ore overburden alkali-activated material matrix shows the formation of a dense matrix contain gels. However, the presence of iron (Hematite) and silica (Quartz) remain unreacted phases from the starting raw material.

- The mechanical properties and microstructural characterization of the calcined iron ore overburden alkali-activated material could be improved by combining with other rich aluminosilicate materials. Besides, find the optimum ratio for the precursor to activator ratio for future studies

\section{Acknowledgments}

The authors express their acknowledgments to the Brazilian development agencies CAPES, CNPq and Fapemig. Laboratories of the Nuclear Technology Development Center (CDTN / CNEN) by staff, space, materials supplied and tests performed.

This work was partially financed by Portuguese national funds through FCT - Foundation for Science and Technology, IP, within the research unit C-MADE, Centre of Materials and Building Technologies (CIVE-Central Covilhã-4082), University of Beira Interior, Portugal.

\section{References}

[1] T. Bakharev, Resistance of geopolymer materials to acid attack. Cement and Concrete Research, 35 (2005) 658-670.

[2] Melo, C. R., \& Riella, H. G. Síntese de zeólita tipo NaA a partir de caulim para obtenção de zeólita 5A através de troca iônica. Cerâmica, 56(340), 340-346 (2010).

[3] A. M. M. Al Bakria, H. Kamarudin, M. BinHussain, I. K. Nizar, Y. Zarina, \& A. R. Rafiza, The Effect of Curing Temperature on Physical and Chemical Properties of Geopolymers. Physics Procedia, 22 (2011) 286-291. https://doi.org/10.1016/J.PHPRO. 2011.11.045

[4] Davidovits, J. Properties of geopolymer cements, In: Proceedings of the First International Conference Álcaline Cements and Concretes. Ucrânia. p.131-149. (1994) 
[5] A. Hasanbeigi, L. Price, \& E. Lin, Emerging energy-efficiency and CO2 emissionreduction technologies for cement and concrete production: A technical review. Renewable and Sustainable Energy Reviews, 16 (2012) 6220-6238. https://doi.org/ 10.1016/J.RSER.2012.07.019.

[6] Borges, P. H. R.; Lourenço, T. M. F.; Foureaux, A. F. S.; Pacheco, L. S. Estudo comparativo da análise de ciclo de vida de concretos geopoliméricos e de concretos à base de cimento Portland composto (CP II),Ambiente Construído, Porto Alegre, v. 14, n. 2, p. 153-168, abr./jun. (2014)

[7] Alves, C. V., Froener, M. S., Longhi, M., Rodríguez, E. D., \& Kirchheim, A. P. Avaliação da resistência mecânica em geopolímeros a base de cinza pesada mediante otimização de cura térmica. Ambiente Construído, 15(3), 7-18. Epub September 00, (2015).https://dx.doi.org/10.1590/s1678-86212015000300022

[8] Davidovits, J. Geopolymers: inorganic polymeric new materials, Journal of Thermal Analysis and calorimetry, 37(8), 1633-1656. (1991).

[9] H. Xu and J.S.J. van Deventer "The geopolymerization of aluminosilicate minerals", International Journal of Mineral Processing 59. 247-266 (2000).

[10] N. Sedira, J. Castro-Gomes, \& M. Magrinho, Red clay brick and tungsten mining waste-based alkali-activated binder: Microstructural and mechanical properties. Construction and Building Materials, 190 (2018) 1034-1048. https://doi.org/10.1016/ J.CONBUILDMAT.2018.09.153.

[11] R. Arellano Aguilar, O. Burciaga Díaz, J.I. Escalante García Lightweight concretes of activated metakaolin-fly ash binders, with blast furnace slag aggregates. Construction and Building Materials, 24 (2010), pp. 1166-1175, https://doi.org/10.1016/ j.conbuildmat.2009.12.024 